\title{
Fossils of the
}

Littleton Formation

(Lower Devonian) of

New Hampshire

By A. J. BOUCOT and ROBERT ARNDT

GEOLOGICAL SURVEY PROFESIONAL PAPER 334-B

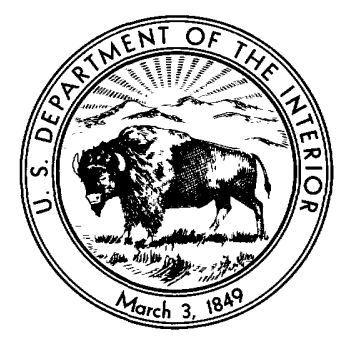

UNITED STATES GOVERNMENT PRINTING OFFICE, WASHINGTON : 1960 
UNITED STATES DEPARTMENT OF THE INTERIOR

FRED A. SEATON, Secretary

GEOLOGICAL SURVEY

Thomas B. Nolan, Director

For sale by the Superintendent of Documents, U.S. Government Printing Office Washington 25, D.C. - Price 25 cents (paper cover) 


\section{CONTENTS}

\begin{abstract}
.
Introduction

Age of the Littleton formation.

Geology of the Devonian fossil-collecting locality on Dalton Mountain.
\end{abstract}

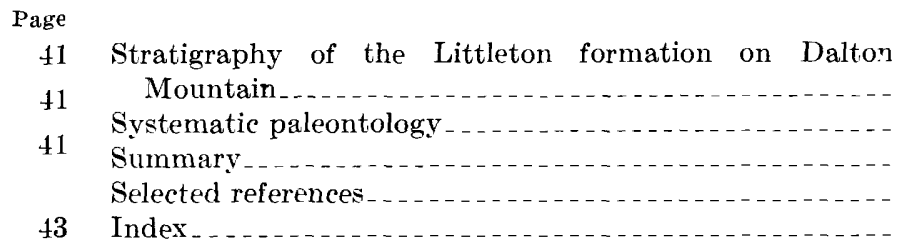

Page

\section{ILLUSTRATIONS}

[Plates 1-3 follow index]

Plates 1, 2. Brachiopods from the Littleton formation.

3. Brachiopods and other fossils from the Littleton formation.

Figure 3. Index map showing quadrangles cited in text $\ldots$

4. Geologic map and cross-section of area adjacent to the Devonian fossil-collecting locality, Dalton Mountain, Whitefield quadrangle, N.H.

\section{TABLES}

TABLE 1. Distribution of fauna from the Littleton formation of New Hampshire and the Moose River sandstone (upper part) of northern Maine 



\title{
SHORTER CONTRIBUTIONS TO GENERAL GEOLOGY \\ FOSSILS OF THE LITTLETON FORMATION (LOWER DEVONIAN) OF NEW HAMPSHIRE
}

\author{
By A. J. Botcot and Robert Arndt
}

\begin{abstract}
Reexamination and study of fossils collected from 3 localities in New Hampshire show the presence of the brachiopods A $m p h i$ genia and Eoderonaria cf. E. arcuata at 2 of the localities. The evidence suggests a correlation of the containing strata with the Camden chert (Lower Devonian) of Tennessee. All the fossils are from slightls metamorphosed (chlorite zone) strata of the Littleton formation in northern New Hampshire. Fossils from highly metamorphosed (sillimanite zone) rocks correlated with the Littleton formation are determined to be of post-Early Ordovician age. Several thousand feet of unfossiliferous post-Nilurian rocks, below the fossiliferous strata (Littleton formation) in the Littleton (quadrangle, are present in part of the adjoining Whitefield quadrangle. The absence of these strata in part of the Whitefield quadrangle mas be due to nondeposition or to erosion prior to deposition of strata of Camden age.
\end{abstract}

\section{INTRODUCTION}

The slightly metamorphosed fossiliferous beds of the Littleton formation crop out in the Littleton, Moosilauke, and Whitefield quadrangles of northwestern New Hampshire (fig. 3). Devonian fossils were first reported from this area by F. H. Lahee (1912). A previous study of the fauma by Cleares (Billings and Cleaves, 1934) concluded that the strata which yielded the fossils are of Oriskany age. Restudy of the fossils available to Cleares, plus those obtained from a new locality located by Arndt in the Whitefield quadrangle (collected by Boucot and others) demonstrates that the faunas are of Camden rather than of Oriskany age. ${ }^{1}$ The locality in the Whitefield quadrangle was visited in the summer of 1949 by M. P. Billings, K. FowlerBillings, and the authors.

The Littleton formation is the only formation in New Hampshire which has yielded generically identifiable fossils of Early Deronian age. All the speci-

1 The Camden chert, in Boucot's opinion. is of Early Deronian age as it is a correlative at least of part of the lower Ensian portion of the standard section for the Deronian in the Rhineland. Eury.4pirife (upper part) is very similar to Euryspirifer hercyniae (Giebel) which characterizes the lower Emsian. mens are slightly metamorphosed. The Littleton has well-developed slaty cleavage and porphyroblasts of pyrite with pressure shadows of fibrous quartz (often in the beaks of the brachiopods). Metamorphism renders the specific identification of the fossils difficult. The nearest fossiliferous beds of similar age ar to the northeast in Somerset County, Maine (upper part of the Moose River sandstone).

The following fossil-collecting localities aro cited in text:

1. Pageau Farm (Tip Top Hill, Ioc. 8 of Billings and Cleaves, 1934), Littleton quadrangle, Grafton County. N.H. USGS SD-3247.

2. Mormon Hill (loc. 11 of Billings and Cleaves, 1934), Littleton quadrangle, Grafton County, N.H.

3. Mount Clough, Moosilauke quadrangle, Grafton Counts, N.H.

4. Dalton Mountain, Whitefield quadrangle, Coos Counts, N.H. USGS SD-3248. Two and three-quarters miles northwest of Whitefield, or one-half of a mile N. $10^{\circ}$ E. of knob 2,000 feet elevation on northeast ent of Dalton Mountain. (See fig. 4 .)

\section{AGE OF THE LITTLETON FORMATION}

The fossils identified in the faunas collected from the Littleton formation and also the ones that are common to the upper part of the Moose River sands'one are shown on table 1. Inspection of table 1 indicates that the faunas from the Pageau Farm, Mormon Fill, and Dalton Mountain are very similar and therefore are concluder to be of the same age. The forms common to both the faunas of the Littleton formation and that of the upper part of the Moose River sandstone suggests that these two units are of the same age.

The presence of $A m p h i g e n i n$ in three of the above mentioned faunas indicates that they are to $b^{n}$ correlated with the zone of Amphigenin which elserhere in North America (Cloud, 1942, p. 7t; Cooper, 1942, chart) is thought to be restricted to strata of Onondaga age. In addition, the presence of highly convex speci- 


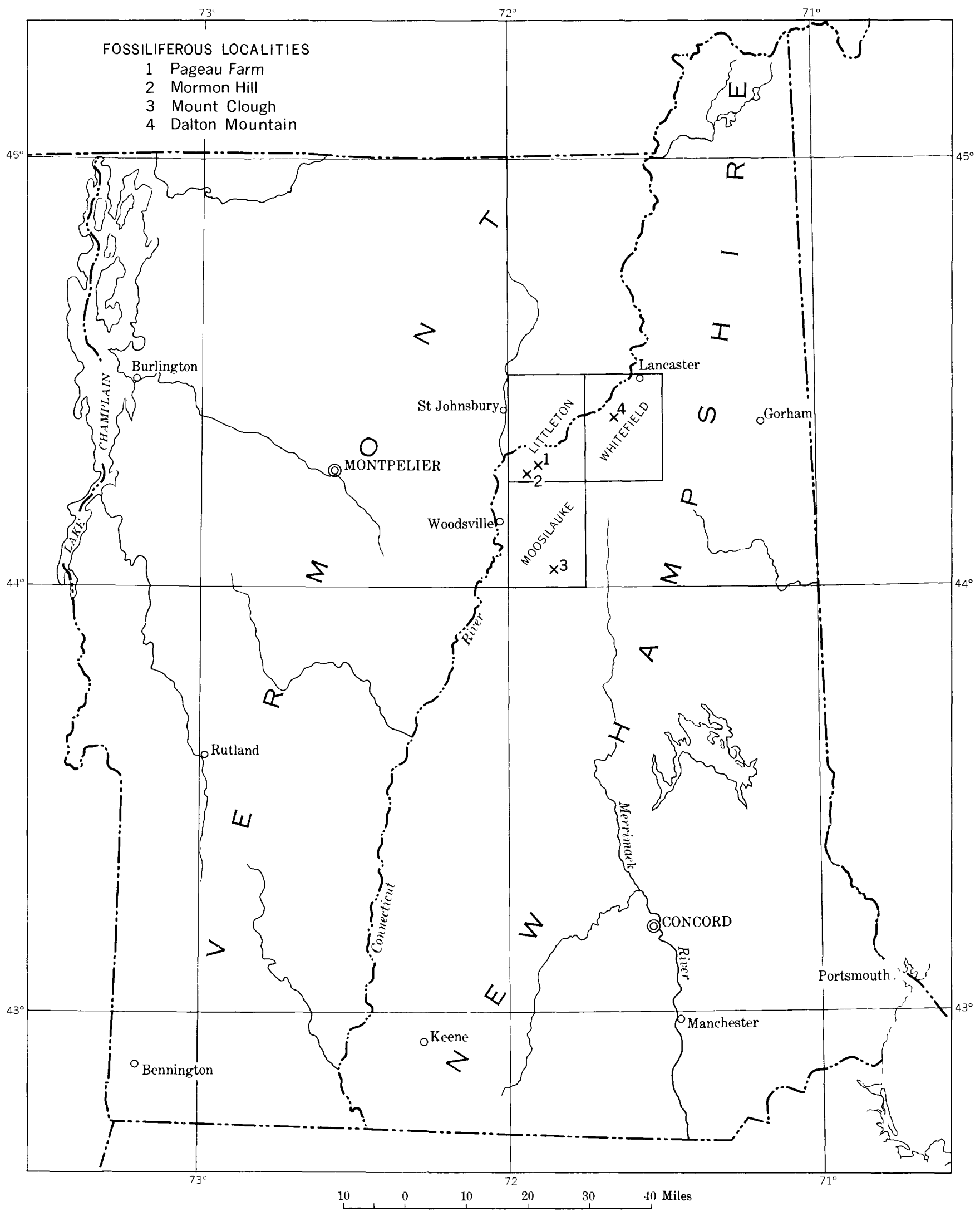

Ftgure 3,- Index map showing quadrangles cited in text. 
TABLE 1.-Distribution of fauna from the Littleton formation of New Hampshire and the Moose River sandstone (upper part) of northern Maine

\begin{tabular}{|c|c|c|c|c|c|c|}
\hline \multirow[b]{2}{*}{ Fossil } & \multicolumn{5}{|c|}{ Locality } & \multirow[b]{2}{*}{ Known stratigraphic range } \\
\hline & $\begin{array}{c}\text { Dalton } \\
\text { Mountain }\end{array}$ & $\begin{array}{c}\text { Pageau } \\
\text { Farm }\end{array}$ & $\begin{array}{c}\text { Mormon } \\
\text { Hill }\end{array}$ & $\begin{array}{l}\text { Species com- } \\
\text { mon to Moose } \\
\text { River sand- } \\
\text { stone (upper } \\
\text { part) }\end{array}$ & $\begin{array}{l}\text { Mount } \\
\text { Clough }\end{array}$ & \\
\hline $\begin{array}{l}\text { Unidentified orthoid brachiopod } \\
\text { Rhipidomelloides musculosa solaris. } \\
\text { Costellirostra sp. } \\
\text { Atrypa "reticularis", } \\
\text { Euryspirifer cf. E. atlanticus } \\
\text { Brachyspirifer cf. B. perimele } \\
\text { Protoleptostrophia cf. P. blainvillei } \\
\text { Schuchertella? sp. } \\
\text { Leptaena "rhomboidalis", } \\
\text { "Chonetes" cf. "C." nectus } \\
\text { Eodevonaria cf. E. arcuata. } \\
\text { Amphigenia ef. A. parva } \\
\text { Prionothyris? sp. } \\
\text { Brachiopod?. } \\
\text { Unidentified pterineoid pelecypod } \\
\text { Pelecypod, unidentified } \\
\text { Tentaculites sp. }\end{array}$ & 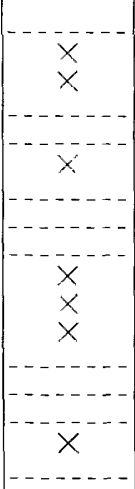 & 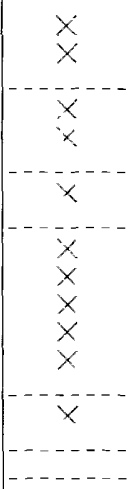 & 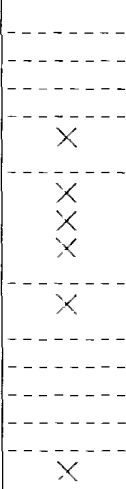 & $\begin{array}{c}x^{-\cdots} \\
x^{x} \\
x \\
x \\
x \\
x \\
x \\
x \\
x \\
x \\
x \\
\cdots\end{array}$ & 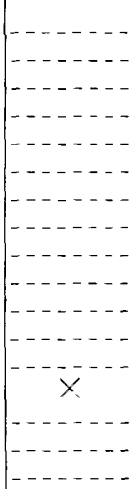 & $\begin{array}{l}\text { Late Early Devonian. } \\
\text { Late Early Devonian. } \\
\text { Silurian and Devonian. } \\
\text { Late Early Devonian. } \\
\text { Late Early Devonian. } \\
\text { Silurian to Mississippian. } \\
\text { Ordovician to Mississippian. } \\
\text { Late Early Devonian. } \\
\text { Late Early Devonian. } \\
\text { Late Early Devonian. } \\
\text { Late Early Devonian. }\end{array}$ \\
\hline
\end{tabular}

mens of Eodevonaria, and spiriferoids similar to Euryspirifer atlanticus are suggestive of a post-Oriskany age since these forms have not previously been reported from strata of Oriskany age or older.

The faunules obtained from the Littleton formation in the Littleton and Whitefield quadrangles occur in structurally isolated synclines from which the strata cannot be traced directly into the adjacent highly metamorphosed rocks with which they have been correlated.

At Mount Clough (fig. 3, loc. 3) two specimens were obtained from the metamorphic rocks correlated with the unmetamorphosed Littleton formation (Billings and Cleaves, 1935, p. 530-536). Both specimens were identified as brachiopods by Cleaves, and the better specimen (pl. 3, fig. 26) as "Spirifer sp. indet." The better specimen was probably a coarsely plicated bivalve, but no basis for reliable phyletic assignment, much less a generic assignment, exists. It is Boucot's opinion, after studying various faunas of early Paleozoic age from the northern Appalachians, that the specimens probably are brachiopods rather than pelecypods, although this opinion cannot be proved on a morphologic basis. If the specimens are brachiopods or pelecypods, it is probable that the containing beds are of post-Early Ordovician age. In Boucot's opinion the better specimen could be assigned to any coarsely plicate brachiopod, including forms such as Plutystrophic and Howellella.

More detailed assignment of the strata must be based on stratigraphic sequence and lithologic similarity rather than on any fossil evidence.
As recognized by Billings and Cleaves (1935, p. 534), these specimens from Mount Clough were not sufficiently diagnostic to date the enclosing rocks. They assigned the rocks to the Littleton formation on the basis of stratigraphic position and lithologic cheracter.

Because beds of massive gray sandstone at locality 2 are very poorly exposed, no attempt was made to determine their stratigraphic position within the sandy member. Cobbles of quartzite of the type found in the Albee formation are present in an outcrop of conglomerate that is approximately 250 feet west of locality 2 (fig. 4). Their large size suggests that the conglomerate lies relatively close to the contact with the Albee formation. The relation of bedding to cleavage indicates that a syncline lies to the southeast as at locality 2 .

\section{GEOLOGY OF THE DEVONIAN FOSSIL-COLLECTING LOCALITY ON DALTON MOUNTAIN}

Fossils of Camden age are found in two exposures on the northwest limb of the Dalton Mountain subsidiary syncline (fig. 4) (Billings, 1955). The rocks at both exposures are slaty sandstone of the Littleton formation. At locality 1, which has yielded the most fossils and from which all the described material has come, the strata lie between 65 and 170 feet abve the base of the sandstone, depending on whether the beds are repeated by folding or dip uniformly toward the southeast, with no minor folding. Field data indicate the presence of some minor folding, but its extent is undetermined because of the small size and scattered 


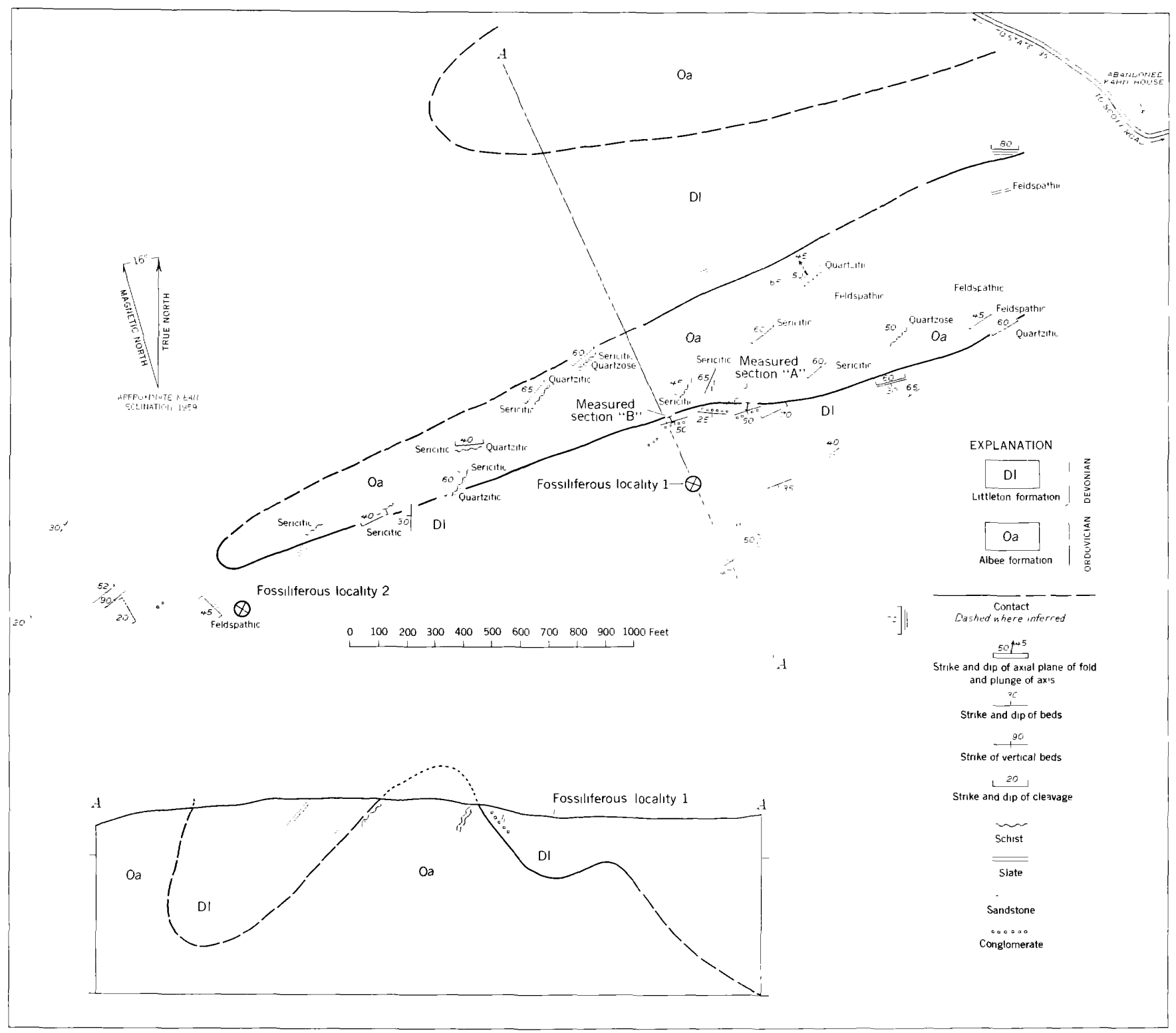

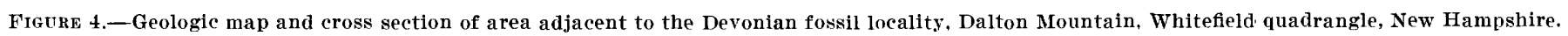

nature of the outcrops of essentially massive, slaty sandstone. General structural relations are shown in the cross section (fig. 4 ).

North of locality 1 , the base of the Littleton formation consists of quartz-pebble conglomerate, gray quartzite, and dark-gray slaty sandstone that lie on the Albee formation. The contact between the formations is not exposed, but at one place it occurs within a corered zone 15 feet wide. The character of the base of the Littleton formation is suggested in two sections measured across the strike of the beds at this locality and shown below:

\section{Sertion A of figure 4}

Extensive covered zone

C'onglomerate

Feet

Quartzite_-_-_-_-_-_ $11 / 2$

Gap and lateral offset_-_._-_._- 2

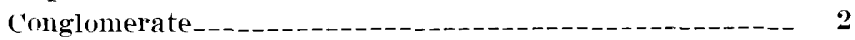

Covered zone_._._._-_._- 15

Albee formation

Section $B$ of figure $4 \quad$ Feet

Conglomerate-_-_. 1

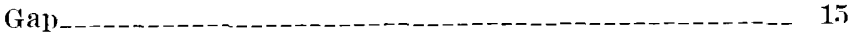

Gray sandstone._- 3

Gap and lateral offset

Conglomerate 
Quartzite_- Feet

Conglomerate._._. 1

Quartzite-_-_-

Gap and lateral offset_... 6

Gray sandstone

No other outcrops in this area

Because beds of massive gray sandstone at locality 2 are very poorly exposed, no attempt was made to determine their stratigraphic position within the sandy member. Cobbles of quartzite of the type found in the Albee formation are present in an outcrop of conglomerate that is located approximately 250 feet west of locality 2 (fig. 4). Their large size suggests that the conglomerate lies relatively close to the contact with the Albee formation. The relation of bedding to cleavage indicates that a syncline lies to the southeast as at locality 1.

\section{STRATIGRAPHY OF THE LITTLETON FORMATION ON DALTON MOUNTAIN}

Fossils of Camden age have been found at three localities in the slightly metamorphosed strata of the Littleton formation in northern New Hampshire (fig. 3). In the Littleton quadrangle, at the Pageau Farm and Mormon Hill, diagnostic fossils occur about 2,500 to 3,000 feet above the base of the Littleton formation (Billings and Cleaves, 1934, p. 422), whereas on Dalton Mountain in the Whitefield quadrangle they occur about 65 to 170 feet (depending on whether the beds are repeated by folding or dip uniformly toward the southeast) above the base of the formation. In the Littleton quadrangle, as pointed out by Billings (1937), no fossils have been found in the lower 2,000 feet of the Littleton formation (which occurs in an isolated canoeshaped syncline). Moreover, the formation rests with apparent conformity upon the Fitch formation, of Silurian age (Billings, 1937). Although older Lower Devonian fossils have not been found in the 2,500 feet of beds underlying those that contain fossils of Camden age in the Littleton quadrangle, there is no a priori reason to conclude that these barren beds are of the same age as those that contain fossils (Billings and Cleaves, 1934 , p. 422 ).

The Littleton formation of Dalton Mountain occurs in a doubly plunging syncline. A small central anticline divides the doubly plunging syncline of Dalton Mountain lengthwise into two subsidiary synclines (Billings, 1955, geologic map).

Black slate interbedded with thin white to gray quartzite is most abundant in the northwestern subsidiary syncline, and at the southwestern end of Dalton Mountain in the southeastern subsidiary anticline. Slaty sandstone is abundant in the southeastern sub$5072200-60--2$ sidiary syncline, especially at the northeastern end of Dalton Mountain, where it contains a conspicuous basal conglomerate that lies both on black slate of the northwestern subsidiary syncline and on the Albee formation. The sequence of beds within the Littleton formation of the northeastern part of Dalton Mountain, from base to top, is black slate (with thin gay to white quartzite), conglomerate, and slaty sandstone. This is similar to the sequence within the Littleton formation in the Littleton quadrangle except that there are, in addition, volcanic rocks associated with the conglomerate, which is made up largely of volcanic material (Billings, 1937).

Direct measurement of the thickness of the Littleton formation on Dalton Mountain is not possible because of relatively poor exposure. Billings (1937, p. 474 475) has shown that the ratio of apparent thickness to breadth of outcrop is 1 to 2 in vertical beds northwest of the Ammonoosuc thrust in the Littleton quadrangle. If this relation holds on Dalton Mountain, the black slate of the northwestern subsidiary syncline might be about 1,500 feet thick, for its dip averages $45^{\circ} \mathrm{NW}$, over a zone about 4,300 feet broad. Similarly, the thickness of slaty sandstone of the southeastern subsidiary syncline might be approximately 1,200 feet, and the total thickness of the Littleton formation here at the widest part of the zone of outcrop might be about 2,700 feet.

The Littlet on formation of Dalton Mountain lies on top of rocks of pre-Silurian and Silurian age. Rocks of pre-Silurian age include the Albee formation, which consists of interbedded quartzite, slate, and phyllite; and overlying Ammonoosuc volcanics of slaty, phyllitic, and schistose tuffs, flows, breccia, conglomerate, slate, and quartzite. Small patches of conglomerate, arkose, and dolomitic slate, assigned to the Fitch formation of Silurian age on the basis of similar litl ology, lie unconformably on the pre-Silurian rocks in scattered localities. The black slate of the Littleton formation lies on the Albee formation in the western subsidiary syncline; on Ammonoosuc volcanics at the southwestern end of Dalton Mountain; and locally on rocks of the Fitch formation. At the north end of Dalton Mountain gray, slaty sandstone and basal conglomerate (consisting of pebbles of vein quartz plus quartzite similar to that of the Albee formation, embedded in a dark-gray, slaty sandstone matrix) of the Littleton formation lie on the Albee formation.

Whereas fossils date the slaty sandstone as of Camden age, the black slate, lacking fossils, is undated except that it is younger than the beds assigned to the Fitch formation and could be either of Silurian age or Early Devonian age. 
The patchy occurrence of the Fitch formation in the Dalton Mountain area requires either that uplift and erosion, renewed after deposition of the Fitch formation, stripped most of it; or that the Fitch formation was accumulated here only in locally inundated areas during the Silurian, prior to the widespread deposition of the black muds of the Littleton formation.

The widespread distribution of the Littleton formation over rocks of pre-Sihurian age indicates that the older rocks were uplifted and eroded before Littleton time began.

It has been recognized that the basal beds of the Littleton formation are contrastingly black slate, conglomerate, or slaty sandstone in different areas and that the conglomerate and slaty sandstone on Dalton Mountain and elsewhere are of Camden age. The close proximity on Dalton Mountain of areas in which slaty sandstone and conglomerate are the basal beds of the Littleton formation with those in which black slate is the basal part (fig. t) requires explanation. Three possible interpretations are suggested:

The area at the northeast end of Dalton Mountain was one of nondeposition during the accumulation of the black mud of the Littleton formation elsewhere.

While black argillaceous sediment accumulated elsewhere, older rocks in a positive area at the northeast end of Dalton Mountain were being eroded and produced coarse clastic sediment which was deposited to the southeast.

Local uplift and erosion followed widespread deposition of the black muds of early Littleton time and exposed the underlying Albee formation at the northern end of Dalton Mountain. Rock debris eroded from the Albee formation and black mud from the lower part of the Littleton formation were incorporated in the conglomerate and slaty sandstone of Camden age.

Of these three possible explanations the writers prefer that which explains the black slate and conglomerate belonging to the lower part of the Littleton formation on Dalton Mountain as facies equivalents of the same age. However, until fossils are found in the black slate, or until more detailed fieldwork reveals an actual intertonguing relation between the two, the above conclusion cannot be considered to have been proved. It would be very desirable to restudy the stratigraphic relations existing within the fossiliferous Early Devonian rocks of northern New Hampshire with a view toward solving this question.

\section{SYSTEMATIC PALEONTOLOGY}

The specimens studied by Cleaves (Billings and (leaves, 193t) were reexamined, and his specimens are refigured in this paper. Plate and figure numbers in the following discussions are those of this paper. Catalog numbers of the Museum of Comparative Zoology, Cambridge, Mass., are cited as MCZ; those of the U.S. National Museum as USNM.

\section{Genus RHIPIDOMELLOIDES Boucot and Amsten, 1958}

Rhipidomelloides musculosa (Hall, 1857) solaris (Clarke, 1907) Plate 1, figures 2-14

Rhipidomella musculosa Hall, var. solaris Clarke, 1907, New York State Mus. Bull. 107, p. 284, figs. 1, 3 [not fig. 2].

Clarke, 1909, New York State Mus. Mem. 9, pt. 2, p. 88, pl. 21, figs. 8, 10-11 [not fig. 9].

platyorthis circularis Cleaves, 1934, [not Sowerby], Am. Jour. Sci., v. 28 , p. $427-430$, pl. 1 , figs. $2,3,6$.

('honetes canadensis Cleaves, 1934, [not Billings. 1874], p. 431432, pl. 1, figs. $5,7,8$.

?schizophoria sp. indet. Cleaves. 1934, p. 433.

Exterior.-Subcircular to transversely elliptical, unequally biconvex, the brachial valve with greater degree of convexity than the almost flat pedicle valve, which may be weakly sulcate. Hinge line short. Anterior commissure rectimarginate. Notothyrium filled by stout cardinal process. Pedicle interarea short. Surface multicostellate, increase in number of costellae by bifurcation and implantation. Pedicle interarea apsacline, brachial interarea orthocline.

Pedicle interior.-Delthyrial cavity shallow, dental plates anterolaterally merging with low ridges surrounding posterior half of muscle area and diverging at an angle of $60^{\circ}$ to $110^{\circ}$. Hinge teeth short, stout, and diverging at same angle as dental plates. Muscle area very large and flabellate; may extend anteriorly almost to anterior margin. Anterior and lateral margins delicately crenulated with flat, usually grooved crenulations. Flabellate, paired adjustor-diductor scars, separated in median line by low, sharp nyophragm, enclose small posteromedian adductor scars. Adductor scars paired, elongate, elliptical, anterior of pedicle callist, medially divided by myor hragm.

Brachial interior.-Dental sockets op n, brachiophores diverging at angle corresponding to that of hinge teeth. Ponderous cardinal process extends to posterior margin; posterior face tilted anteriorly; anterior face tilted steeply posteriorly. Muscle area quadripartite, divided by low rounded septa. Muscle area extends anteriorly about two-fifths of length; anterior scars the larger. Brachiophores long, supported anteriorly by secondary material, tips pointed.

Discussion.-This subspecies was first described by (larke $(1907)$, as a variety of "Rhipidomella" musculosa (Hall, 1857), from material collected by Olof Nylander. In the original description, "Moosehead Lake, Baker Brook Point; Brassua Lake east side; 
Moose River at Stony Brook, Maine" are listed as localities (Clarke, 1907, p. 284). Clarke later gave the same locality list as above (Clarke, 1909, p. 88 ) ; on page 208 of the same volume, however, localities were assigned to four figured specimens (three of which had previously been figured in Clarke, 1907)-figures 8, 10, and 11 cited as from Tomhegan Point, Moosehead Lake, and figure 9 from .Jackman Farm. Since rocks and fossils of only Oriskany age occur on Tomhegan Point and $R$. musculosa solaris is limited in both Maine and New Hampshire to beds of Camden age, it seems clear that the specimens represented by figures 8,10 , and 11 were collected from beds of Camden age probably on Baker Brook Point. Figure 9, representing a brachial valve, possesses the cardinalia and other characters of Platyorthis; it is, therefore, reasonable that it was collected from beds of Oriskany age at Jackman Farm.

Clarke's original description indicates that he founded his variety, considered here a subspecies, upon the characters of the pedicle valve: "These are all small shells with the enormous adductor (sic diductoradductor) scar in a state of high development. These shells are somewhat less circular, more transverse than the New York and Grande Grève Oriskany specimens of $R$. musculosa, but their specific identity is not greatly veiled" (Clarke, 1907, p. 284). It is recommended that Clarke's name " $R$. musculosa solaris" be retained for the forms whose pedicle valves are figured in accordance with his implied intent.

Restudy of Cleave's collections shows that the specimens figured by him as Platyorthis rircularis ( $\mathrm{pl}$. 1, figs. $9,12,13)$ are actually Rhipidomelloides. In addition sereral specimens figured by him as Chonetes canadensis (pl. 1, figs. $7,8,10$ ) are also Rhipidomelloides, as is another assigned to ?Schizophoria sp. indet. (pl. 1, fig. 14).

The crenulations on the internal margins of Platyorthis are very distinctive owing to their branching character, as opposed to the unbranched crenulations present in rhipidomellids. "Chonetes" canadensis Billings, 1874, does not have internal margin crenulations, a subcircular outline or nearly so large a deeply impressed, flabellate muscle field in the pedicle valve. On the other hand it does have a short posterior median septum in the pedicle valve which is absent in Rhipidomelloider. Chonetids of the " $C$." cunadensis type do not possess dental plates, whereas Rhipidomelloides has prominently developed dental plates.

Holotype: The impression of a pedicle interior as figured by Clarke (1907, p. 284, right side of page, New York state Mus. type $\mathrm{N}_{0.850 .)}$ ) is here selerted as the holotype.

occurence: Pageau Farm and Dalton Mountain.
Geologic location: Upper part of the Littleton formation in the Littleton quadrangle and base of the Littleton fo"mation in the adjoining Whitefield quadrangle.

Geographic distribution: Somerset County, Maine ( upver part of the Moose River sandstone of Camden age): northern New Hampshire; the Green Pond area of New Jersey, ("Schizophoria sp. cf. S. striatula (Schlotheim)" of Weller [1903] from the Kanouse sandstone of Camden age): possibly the " $R$. alsa? Hall" of Dunbar (1919) from western Tennessee (Camden chert of late Early Devonian age).

Figured specimens: MCZ 8666; 8667, 8668; 8675: 8677; 8680; USNM 125503, $125518 \mathrm{~A}, 125519,125526,125528$.

Unfigured specimens: MCZ 8669 A, B, D.

\section{Unidentified orthoid brachiopod}

Plate 1, figure 1

Chonetes sp. indet. Cleaves, 1934, Am. Jour. Sci., v. 28 p. 433.

Remarks.-A single impression of the interior of a pedicle valve was referred by Cleaves to Chonetes sp. indet., but the presence of a cordate muscle field laterally bounded by short dental lamellae and the impress upon the internal impression of radial costellae are indicative of an orthoid. The material is too poorly preserved to be generically identified.

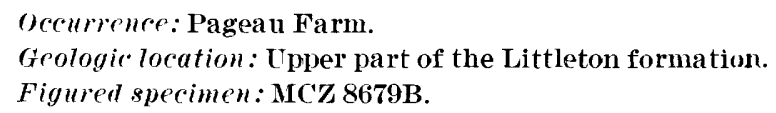

Remarks.-A few specimens from Dalton Mcuntain possess the generic characters of Costellirostra. They are somewhat fragmentary but exhibit the form given in the following descriptions.

Exterior.-The exterior is not well enough preserved to ascertain its ornamentation. Biconvex, well-developed sulcus on pedicle valve that extends into a prominent tongue anteriorly and corresponds to the prominent $\mathrm{U}$-shaped anterior margin of the brachial valve. Outline subcircular.

Brachial interior.-Short median septum present at posterior end of valve. Cardinalia not preserved in specimens studied.

Pedicle interior.- Short hinge teeth, muscle field deeply impressed, consisting of large diductor scars surrounding small pair of partly covered adductor impressions. Posterior half of muscle field divided by median septum.

Occurrenre: Dalton Mountain.

Geologic location: Base of Littleton formation.

Geographic distribution: Fastern North America.

Figured specimens: USNM 125513, 125686. 


\section{Genus ATRYPA Dalman, 1828}

Atrypa "reticularis" (Linnaeus, 1767)

Plate 1, figure 17

A. Atrypa reticularis (Linnaeus), Cleaves, 1934, Am. Jour. Sci., v. 28, p. 433.

Remarls.-A single impression of the brachial interior from the Pageau Farm has the characters of $A$. "reticularis" including the characteristic muscle field and impression of the external ornamentation. On the same piece is an impression of the interior of an Amphigenia pedicle valve.

occurrence: Pageau Farm.

Geologic location: Upper part of the Littleton formation.

Geographic distribution: World-wide.

Figured specimen: MCZ 8681.

\section{Genus EUR YSPIRIFER Wedekind, 1923}

Euryspirifer of. E. atlanticus (Clarke, 1907)

Plate 1, figures $18-20$, plate 2 , figures $1-1$

Spirifer primaerus Steininger atlanticus Clarke, 1907, New York State Mus. Bull. 107 p. 260-262.

Spirifer gaspensis Williams and Breger, 1916 [not Billings, 1874] U.S. Geol. Survey Prof. Paper 89, p. 107-113, pl, 4, fig. 7. Spirifer murchisoni Cleaves, 1934, [not Castelnau] Am. Jour. Sci., v. 28 , p. $433-435$, pl. 2 , figs. $1,2,3,4$

Leptocoelia sp. indet Cleaves, 1934, Am. Jour. Sci., v. 28, p. 436. pl. 1, figs. 10-13.

Exterior.-Extemal fine ornamentation destroyed during metamorphism, biconvex, outline subcircular to alate, strongly developed angular fold on brachial valve, well-developed sulcus on pedicle valve, pedicle interarea apsacline and concave, brachial interarea orthocline to gently apsacline, bordered by 6 to 14 lateral plications. Anterior commissure uniplicate and crenulate.

Pedicle interior:-Short, stout dental plates support stubby hinge teeth and laterally enclose deeply impressed muscle field. Impression of muscle field projects posteriorly well behind hinge line. Impression of external plications pronounced.

Brachial interior.-Cardinalia consist of comblike structure sunk into the floor of the notothyrial cavity, discrete hinge plates whose posterior face forms one side of dental sockets. Impression of lateral plications like those of pedicle valve.

Comparison.-Small specimens of Euryspirifer and Acrospirifer have almost identical form, as it is only among the larger specimens that the increased number of lateral plications characterizing Euryspirifer becomes evident. It is not surprising therefore that the hysterolitids from the Pageau Farm were mistakenly associated with Acrospirifer murchisoni. The destruction of fine ornamentation in these shells prevents the generic identification from being positive. Note the absence of crural plates in the brachial valve (pl. 2 , fig. 2), these structures being characteristic of the howellellids. E. intermedius (Hall, 1859) has fewer lateral plications than $E$. atlanticus (Clarke, 1907).

Ocrurrence: Pageau Farm and Mormon Hill.

Geologic location: Upper part of the Littletor formation.

Geographic distribution: Somerset County, Maine (upper part of the Moose River sandstone of Camden age, and northern

New Hampshire.

Figured specimens: MCZ 8662, 8663, 8664, 8682 А, 8682 B, $8682 \mathrm{C}, 8682 \mathrm{D}$.

Unfigured specimens: MCZ 8661, $8760 \mathrm{~A}-\mathrm{D}$.

\section{Genus BRACHYSPIRIFER Wedekind, 1923}

Brachyspirifer cf. B. perimele Clarke, 1907

Plate 2, figures $5-7$

Spirifer perimele Clarke, 1907, New York State Mus. Bull. 107. p. $253-254$.

Remarks.-The collections from Dalton Mountain contain a few hysterolitids possessing the form of $B$. perimele. They have a relatively broad sulcus bordered by numerous, low, rounded costellae, and have a deeply impressed pedicle muscle field. Unfortunately the material is too poorly preserved to be specifically identifiable.

Occurrence: Dalton Mountain.

Geologic location: Base of Littleton formation.

Geographic distribution: Somerset County, Maine (upper part of Moose River sandstone of Camden aga), and northern New Hampshire.

Figured specimens: USNM 125508 A, 125510, 125524 A.

Genus PROTOLEPTOSTROPHIA Caster, 1939

Protoleptostrophia cf. P. blainvillei (Billin§s, 1874)

Plate 2, figures 8-12

strophomena blainrillei Billings, 1874, Paleozoic fossils : Canada Geol. Survey, p. 28, pl. 2, fig. 1.

Leptostrophia magnifica Cleaves, 1934 [not Hall], Am. Jour. Sci., v. 28 , p. $430-431$, pl. 1 , fig. 1 .

Chometes canadensis Cleaves, 1934 [not Billirgs], Am Jour. Sci., v. 28, p. 431-432, pl. 1, fig. 4.

Remarks.-Most of the available specimens consist of pedicle valves that are indistinguishable from Leptostrophia, but the presence of a brachial interior (pl. 2, fig. 8) showing the absence of either socket plates or a swollen chilidium demonstrate that the leptostrophids from the Littleton formation belong to Protoleptostrophia. The specimen assigned by Cleaves (pl. 1, fig. 4) to "Chonetes" canadensis has the characteristic radial ornamentation of a leptostrophid rather than the interrupted radial ornamentation present in " $C$." cunadensis.

Occurrence: Pageau Farm and Mormon Hill.

Geologic location: Lpper part of the Littleton formation.

Geographic distribution: Eastern North America.

Figured specimens: MCZ 8671, 8671 A, 8674; USNM 125501, $125520 \mathrm{~A}$.

Tnfigured specimens: MCZ 8672 A-D. 
Genus SCHUCHERTELLA Girty, 1904

Schuchertella? sp.

Plate 3, figure 1

Remurks.-A single specimen from Mormon Hill apparently belongs to Schuchertella. It has the form and omamentation of an orthotetacid. It is not possible to indicate the specific affinities of this shell.

Occurrence: Mormon Hill.

Gcologic location: Upper part of the Iittleton formation.

Geographic distribution: Worldwide.

Figured specimen: $\mathrm{MCZ} 8670$.

Genus LEPTAENA Dalman, 1828

Leptaena "rhomboidalis" (Wilckens, 1769)

Plate 3, figure 2

Remarks.-A few fragments from Mormon Hill and the Pageau Farm possess the wrinkled ornamentation and geniculate form of $L$. "rhomboidalis."

Occurrence: Pagea warm and Mormon Hill.

Geologic loration: Upper part of Littleton formation.

Geographic distribution: Worldwide.

Figured specimen: MCZ 8673.

\section{Genus CHONETES Fischer, 1837}

"Chonetes" cf. 'C." nectus Clarke, 1907

Plate 3, figures $3-9$

Chonetes nectus Clarke, 1907, New York State Mus. Bull. 107, p. 263-264, 4 figs.

Chonetes hitchcocki Cleaves, 1934, Am. Jour. Sci., v. 28, p. 432433 , pl. 1. fig. 15 .

Chonetes sp. indet Cleaves, 1934 idem, p. 433, pl. 1, fig. 14.

Chonetes vicinus deffectus Williams and Breger, 1916 [not Hall], U.S. Geol. Survey Prof. Paper 89, pp. 49-52, pl. 3, fig. 8.

Remark's.-The relatively coarsely costellate chonetid from the Pageau Farm and Dalton Mountain is similar in form, as far as can be determined from the poor specimens available, to "Chonetes" nectus. Unfortunately, Cleares" material is too poor to enable one to demonstrate statistically that his "Chonetes hitchcocki" is not a synonym of " $($ '." nectus, but the morphology of the specimens is similar, as is their stratigraphic position; therefore, it seems most reasonable to consider them as synonymous.

Occurrence: Pageau Farm and Dalton Mountain.

Gcologic 7ocation: Luper part of Littleton formation in Littleton quadrangle. and base of Littleton formation in Whitefield quadrangle.

Geographir distribution: Somerset County, Maine ( upper part of Moose River sandstone of Camden age), northern New Hampshire.

Figured sperimens: MCZ 8678 A, C, 8679 A, H. IISNM 125509 , $125.514 \mathrm{~A}, 125514 \mathrm{~B}$.

Unfigured specimens: $\mathrm{MCZ} 8679 \mathrm{C}-\mathrm{G}$.

\section{Genus EODEvonaRIA Breger, 1906}

Eodevonaria cf. E. arcuata (Hall, 1857)

Plate 3, figures 10-13

Remarks.-Highly convex chonetids possessing finely costellate radial ornamentation and a denticulate linge line occur in the Littleton formation. The form, in addition to the denticulate hinge line, indicates that this material should be assigned to Eodevonaria, the most similar species being $E$. arcuata.

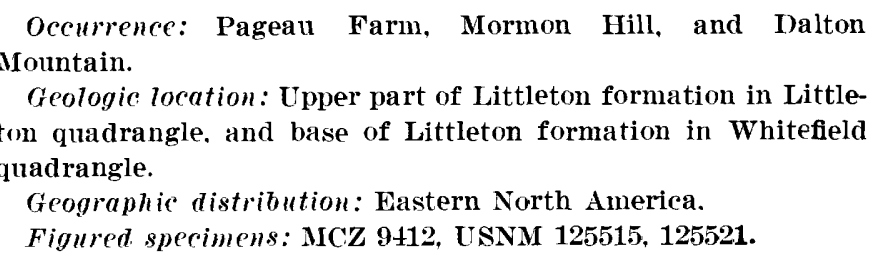

Genus AMPHIGENIA Hall, 1867

Amphigenia cf. A. parva Clarke, 1907

Plate 3, figures $1 \pm-20$

Exterior.-Smooth, biconvex, elongate to subcir $r$ ular in outline, brachial valve gently convex, pedicle valve carinate.

Pedicle interior.-Well-developed spondylium supported by a median septum composed of medially convergent dental plates evident in material from New Hampshire.

Brachial interior.-Long crural plates support a perforate cardinal plate. Adductor muscle field ne rrow and split into four subparallel impressions, separated by low ridges.

Occurrence: Pagean Farm and Dalton Mountain.

Geologic location: Upper part of Littleton formation in Littleton quadrangle, and base of Littleton formation in Whitefield quadrangle.

Geographic distribution: Eastern North America.

Figured specimens: MCZ 8681; USNM 125506. 125608 B, 125.511, 125517 A, 125522, $125523 \mathrm{~B}$.

\section{Genus PRIONOTHYRIS Cloud, 1942}

Prionothyris? sp..

Plate 3, figures 21-25

Exterior-_Subcircular outline, surface smooth except for concentric growth lines, subequally biconvex with pedicle valve having greater convexity, anterior commissure rectimarginate.

Brachial interior:-Short crural plates suppor ${ }^{+}$cardinal plate which is surmounted by terminally bifid cardinal process. Detailed form of cardinal process not known, but suggests Prionothyris; is similar to an undescribed species from upper part of Moose River sandstone. Cardinal plate imperforate. Narrow, medial 
adductor tield weakly impressed and divided medially by low myophragm.

Pedicle interior.-Dental plates obsolete. Muscle field elongate, subovate, divided into a small pair of medial adductor scars entirely surrounded by large, more deeply impressed diductor field. Myophragm divides muscle field medially.

Occurrence: Pageau Farm.

Geologic location: Upper part of Littleton formation in Littleton quadrangle.

Geographic distribution: Eastern North America and Colombia.

Figured specimens: USNM 125500 B, 125504 A, 125512 B, $125516,125527$.

\section{Unidentified pterineoid pelecypod}

Plate 3, figures 29-31

Pterinea radialis Cleaves, 1934 [not Clarke], Am. Jour. Sci., v. 28, pp. 436-437, pl. 2, figs. 5-7.

Remarks.-A few left valves of a pterineoid pelecypod have the external ornamentation and form of Actinopteria textilis, but the material is too poorly preserved for positive identification. Pelecypods of similar aspect have been found in the upper part of the Moose River sandstone.

Occurrence: Pageau Farm.

Geologic location: Ipper part of the Littleton formation.

Figured specimens: MCZ 15056, 15057, 15058.

\section{Unidentified pelecypod}

Plate 3, figure 28

Remarks.-A single impression of the interior of a right valve belonging to a strongly keeled pelecypod with prominent growth lines, and a subrectangular outline was found at Dalton Mountain. The general form is goniophorid, but the specimen is too poorly preserved to be generically identified.

Occurrence: Dalton Mountain.

Geologic location: Base of the Littleton formation.

Figured specimen: USNM 125502 B.

\section{Genus TENTACULITES Schlotheim, 1820}

\section{Tentaculites sp.}

Plate 3, figure 27

Tentaculites schlotheimi Cleaves, 1934 [not Koken], Am. Jour. Sci., v. 28, p. 437 .

Remarkx.-A single poorly preserved tentaculitid was found in the beds at Mormon Hill, but it is too poorly preserved to be specifically identifiable.

Occurrence: Mormon Hill.

(ieologic location: Upper part of the Littleton formation.

Figured specimen: $\mathrm{MCZ} 27907$.

\section{SUMMARY}

The slightly metamorphosed slaty $\mathrm{s}^{\top}$ ndstone and conglomerate of the Littleton formation, which rests unconformably upon pre-Silurian strata at the northeastern end of Dalton Mountain, in the Whitefield quadrangle are of Camden age as is the upper part of that unit in the adjacent Littleton and Moosilauke quadrangles. The lower 2,000 feet of the Littleton formation in the Littleton and Moosilauke quadrangles is unfossiliferous but is bracleted between strata of Silurian and late Early Devonian (Camden) age as are equivalent black slates on the northwest side and southwest end of Dalton Mountain. Paleontologic evidence suggests that the metamorphcsed rocks assigned to the Littleton formation on Mount Clough are of post-Early Ordovician age. The corrolation of the unmetamorphosed Littleton formation with the metamorphosed rocks assigned to this unit must be made wholly on the basis of similar stratigraphic sequence and lithology as Billings concluded (1937).

\section{SELECTED REFERENCES}

Billings, Elkanah, 1874, Paleozoic fossils, v. 2, pt. 1; Canada Geol. Survey, $144 \mathrm{p}$.

Billings, M. P., 1934, Paleozoic age of the rocks of central New Hampshire: Sci., n. ser., v. 40, Jan. 19, 1934, p. 55-56.

1937, Regional metamorphism of the Litt'eton-Moosilauke area : Geol. Soc. America Bull., v. 48, no. 4, p. 463-566.

___ 1955, Geologic Map of New Hampshire: U.S. Geol. Survey.

Billings, M. P., and Cleaves, A. B., 1934, Paleontology of the Littleton area, New Hampshire: Am. Jour. Sci., v. 28, p. 412438 .

1985, Brachiopods from mica schist, Mo»nt Clough, New Hampshire: Am. Jour. Sci., v. 30, p. 530-536.

Clarke, J. M., 1907, Some new Devonic Fossils: New York State Mus. Bull. 107, p. 153-291.

1909, Early Devonic history of New York and eastern North America: New York State Mus. Mem. 9, pt. 2, 250 p.

Clour, P. E., Jr., 1942, Terebratuloid brachiopod ${ }^{`}$ of the Silurian and Deronian: Geol. Soc. America Spec. Pa per 38, $182 \mathrm{p}$.

('ooper, G. A., 1942, Correlation of the Devonian sedimentary formations of North America: Geol. Soc. America Bull., v. 53, p. 1729-1793.

Dunbar, C. O., 1919, Stratigraphy and correlation of the Devonian of western Tennessee: Tennessee Geol. Surrey Bull. $21.127 \mathrm{p}$.

Hall, J., 1857, Descriptions of Paleozoic fossils: New York State Cabinet Natural History, 10th Ann. Rep., p. 39-180.

Lahee, F. H., 1912, A new fossiliferous horizon on Blueberry Mountain in Littleton, New Hampshire: Science, new ser., r. 36, p. $275-276$.

Weller, S., 190:3. Report on Paleontology : Geol. Survey of New Jersey, v. 3, $462 \mathrm{p}$.

Williams. H. S., and Breger, C. L., 1916, The fauna of the Chapman sandstone of Maine including descriptions of some related species from the Moose River sandstone: U.S. Geol. Survey Prof. Paper 89, 347 p. 


\section{IN DEX}

[Italic numbers indicate descriptions]

Page

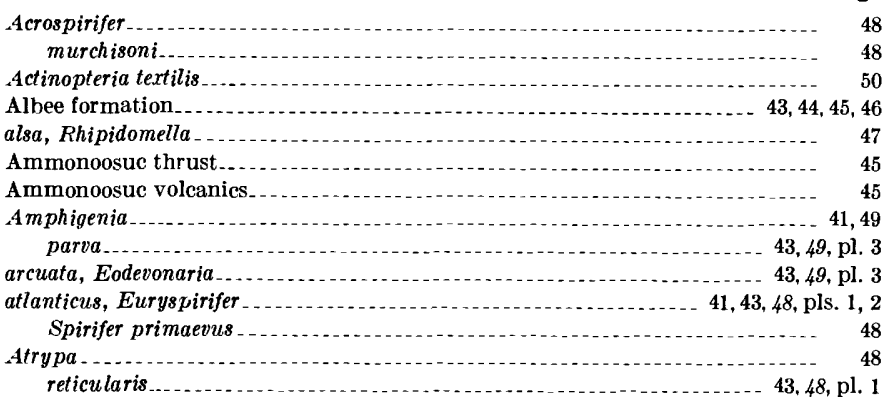

Baker Brook Point.

blainvillei, Protoleptostrophia

Strophomena.

Brachiopod, orthoid, unidentified

Brachyspirifer perimele

Camden age

-.. 46,47

$43,48, \mathrm{pl} .2$

43,47, pl. 1

43,48, pl. 2

Camden chert

Camden faunas

canadensis, Chonetes

Chonetes

canadensis

hitchcocki-

nectus

vicinus deflectus

sp. indet

circularis, Platyorthis

Coos County, N.H

Costellirostra.

$43,45,46,47,48,49,50$

Dalton Mountain

\section{defiecrus, Chonetes vicinus}

Devonian fossil-collecting locality on Dalton Mountain, geology of

Eodenonaria arcuato

3,49, pl. 3

Euryspirifer

atlanticus_. $41,43,48$, pls. 1,2

hercyniae

$41,43,48$, pls. 1,2

intermedius

Fitch formation

45,46

gaspensis, Spirifer

Geology of the Devonian fossil-collecting lccality on Dalton Mountain.

Grafton County, N.H.

hercyniae, Euryspirifer

hitchcocki, Chonetes.

Hou'ellella.

intermedius, Euryspirifer

Jackman Farm

Kanouse sandstone

41,47

41
47,48

47,48

49

pl. 3
49

47,49

46,47

41
47

3,47, pl. 1

Leptaena

rhomboidalis

Leptocoelia sp. indet

Leptostrophia

magnifica...

Littleton fcrmation, age of

stratigraphy of

Littleton quadrangle

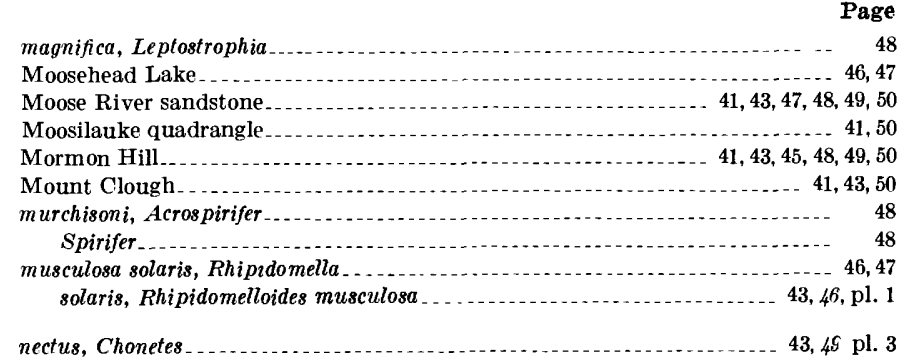

Onondaga age

Oriskany age

Pageau Farm . . . . parva, Amphigenia

Pelecypod, unidentified ............... 43, 50, pl. 3

perimele, Brachyspirifer Spirifer.... 48

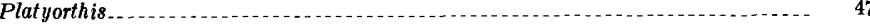

circularis

Platystrophia

primaevus atlanticus, Spirifer-........... 48

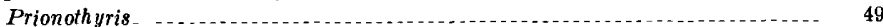

sp . . . . . . . 43, 4S pl, 3

Protoleptostrophia

blainvilleii................ 43, 4\&, pl. 2

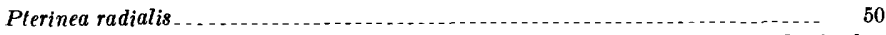

Pterineoid pelecypod, unidentified... 3

radialis, Pterinea

reticularis, Atrypa $\ldots \ldots \ldots$. . . . . . . . . 1

Rhipidomella alsa............ 47

musculosa solaris. 46,47

Rhipidomelloides

musculosa solaris........... 1

rhombordalis, Leptaena

Schizophoria striatula

sp indet. 46,47

schlotheimi, Tentaculites.

Schuchertella

$8 p$.

Selected references......... 50

Silurian age

solaris, Rhipidomella musculosa
$\quad$ Rhipidomelloides musculosa

Somerset County, Maine _....

Spirifer gaspensis

murchisoni............... 48

perimele

primaevus atlanticus

sp. indet........... 43

Stratigraphy of the Littleton formation on Dalton Mountain $\ldots \ldots$

striatula, Schizophoria

Strophomena blainnillei............ 48

Summary
Systematic paleontology

Systematic paleontology

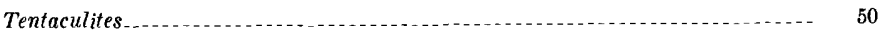

schlotheimi

sp

textilis, Actinopteria

$\begin{array}{lll}\text { Tip Top Hill } & 41\end{array}$

Tomhegan Point

Whitefield quadrangle................ $41,43,44,45,47,49,50$ 

PLATES 1-3 


\section{PLATE 1}

FiguRE 1. Unidentified orthoid brachiopod (p. 47).

Impression of the interior; probably of a brachial valve $(\times 2)$. This specimen is too fragmentary to be assigned generically with any degree of assurance. Pageau Farm. Upper part of the Littleton formation. MCZ 8679 B.

2-14. Rhipidomelloides musculosa (Hall, 1857) solaris (Clarke) (p. 46).

2. Impression of the interior of a pedicle valve $(\times 1)$. Note the flabellate diductor impressions, and the paired adductor impressions located toward the posterior of the specimen. A median septum divides the muscle field. Dalton Mountain. Base of Littleton formation. USNM 125526.

3. Impression of the interior of a pedicle valve $(X 1)$. Note the nature of the muscle field and the impression of the crenulations on the anterior margin. Dalton Mountain. Base of the Littleton formation. USNM $125518 \mathrm{~A}$.

4. Impression of the exterior of a pedicle valve $(X, 1)$. Note the origin of the costellae largely by bifurcation. Dalton Mountain. Base of the Littleton formation. USNM 125519.

5. Impression of the interior of a brachial valve $(X 1)$. Note the quadrilobate impressions of the adductor muscles. Dalton Mountain. Base of the Littleton formation. USNM 125503.

6. Impression of the interior of a brachial valve $(\times 1)$. Note the disposition of the cardinal proness, brachiophores and median septum impressions. Dalton Mountain. Base of the Littleton formation. USNM 125528.

7. Partially exfoliated brachial valve $(\times 2)$. Note the crenulations along the anterior margin and the impression of the broad median septum. Pageau Farm. Upper part of the Littleton formation. MCZ 8677. P1. 1, fig. 8 of Billings and Cleaves, 1934.

8. Anterior three-quarters of impression of interior of pedicle valve $(\times 2)$. Note the median seftum and the crenulation of the anterior margin. Pageau Farm. Upper part of the Littleton formation. MCZ 8675 . Pl. 1, fig. 5 of Billings and Cleaves, 1934.

9. Impression of the interior of a pedicle valve $(\times 1)$. Note the flabellate impression of the muscle field and the elongation due to deformation. Pageau Farm. Upper part of Littleton formation. MCZ 8667 . Pl. 1, fig. 3 of Billings and Cleaves, 1934.

10. Anterior three-quarters of impression of interior of pedicle valve $(\times 2)$. Note the crenulations on the anterior margin, and the impression of the pyrite porphyroblast. Pageau Farm. Upper part of the Littleton formation. MCZ 8676. Pl. 1, fig. 7 of Billings and Cleaves, 1934.

11. Interior of pedicle valve $(X, 2)$. Note the dental plates and the secondary material extending anteriorly from them. Pageau Farm. Upper part of the Littleton formation. MCZ 8666. Counterpart of fig. 12.

12. Impression of the interior of a pedicle valve $(\times 2)$. Note the impression of the pedicle callist and the paired adductor scars. Pageau Farm. Upper part of the Littleton formation. MCZ 8666, Pl. 1, fig. 6, of Billings and Cleaves, 1934 .

13. Impression of the interior of a pedicle valve $(\times 2)$. Note the impression of the dental lamellae. Pageau Farm. Upper part of the Littleton formation. MCZ 8668. Pl. 1, fig. 2 of Billings and Cleaves, 1934.

14. Impression of the exterior of a pedicle valve $\left(\chi_{*} 2\right)$. Note the origin of the costellae largely by bifurcation. Pageau Farm. Upper part of the Littleton formation. MCZ 8680.

15, 16. Costellirostra sp. (p. 47).

15. Impression of the interior of a brachial valve $(\times 2)$. Note the thin median septum. Dalton Mountain. Base of the Littleton formation. USNM 125686.

16. Impression of the interior of a pedicle valve $(\times 2)$. Note the elliptical diductor impressions surrounding the minute adductor impressions. Dalton Mountain. Base of the Littleton formation. USNM 125513.

17. Atrypa "reticularis" (Linnaeus) (p. 48).

Impression of the interior of a pedicle valve $(\times 2)$. Pageau Farm. Upper part of the Littleton formation. $\mathrm{MCZ} 8681$.

18-20. Euryspirifer ef. E. atlanticus (Clarke) (p. 48).

18. Internal impression of a pedicle valve $(\times 2)$. The lateral portions of this specimen are missing. Pageau Farm. Upper part of the Littleton formation. MCZ 8682 B. Pl. 1, fig. 10 of Billings and C'eaves, 1934.

19. Internal impression of a brachial valve $(\times 2)$. Note the lack of crural plates. Pageau Farm. Upper part of the Littleton formation. MCZ 8682 D. P1. 1, fig. 11 of Billings and Cleaves, 1934.

20. Internal impression of a brachial valve $(x .2)$. Pageau Farm. Upper part of the Littleton formation. MCZ 8682 A. Pl. 1, fig. 13 of Billings and Cleaves, 1934. 
GEOLOGICAL SURVEY
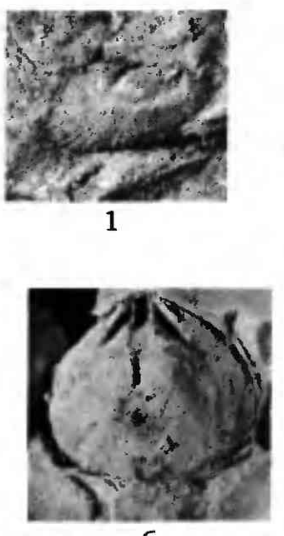

6

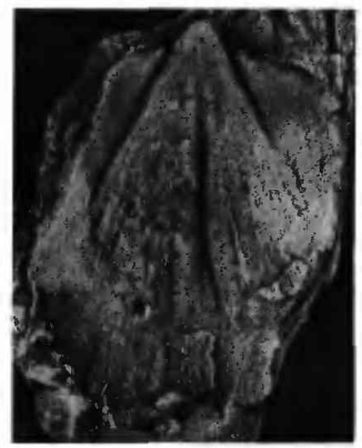

9

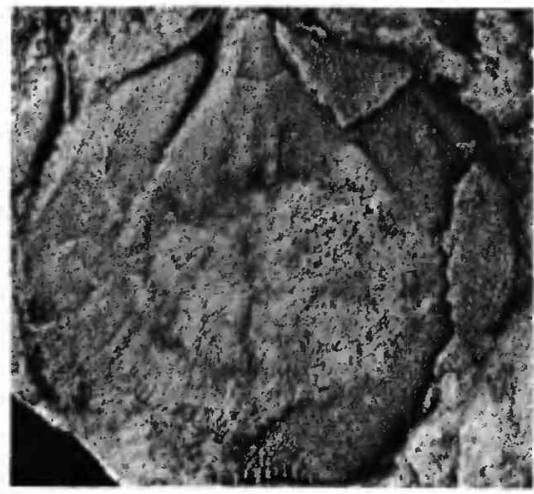

12

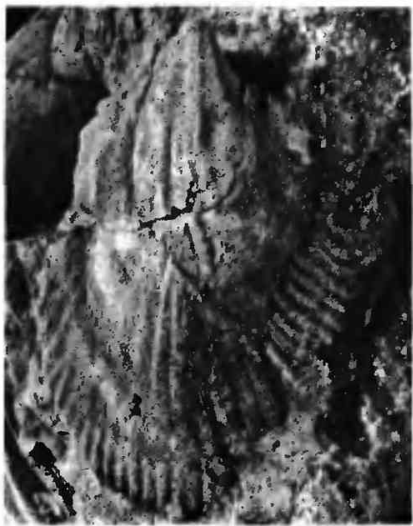

17

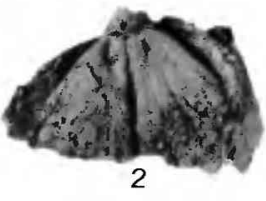

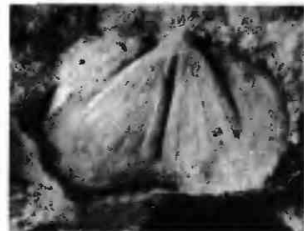

3
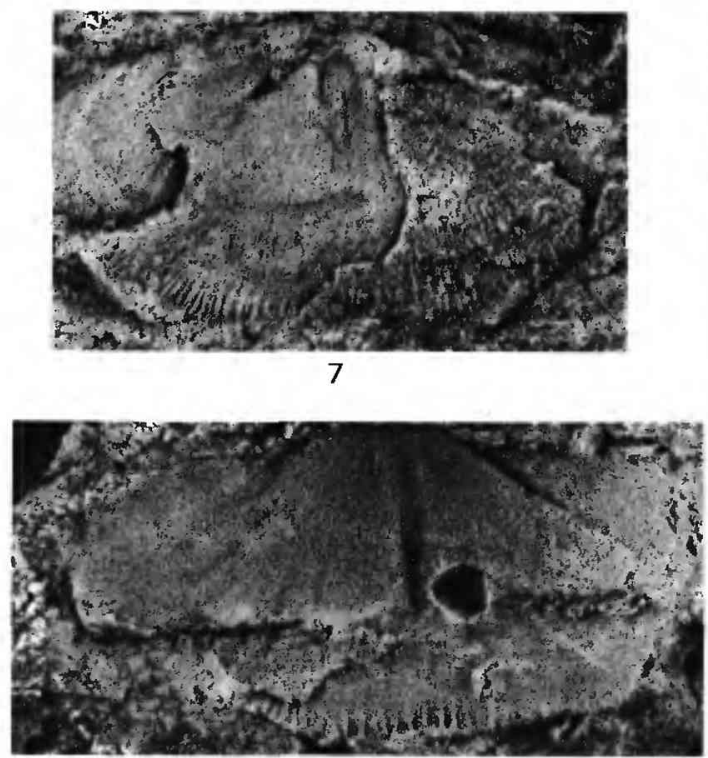

10

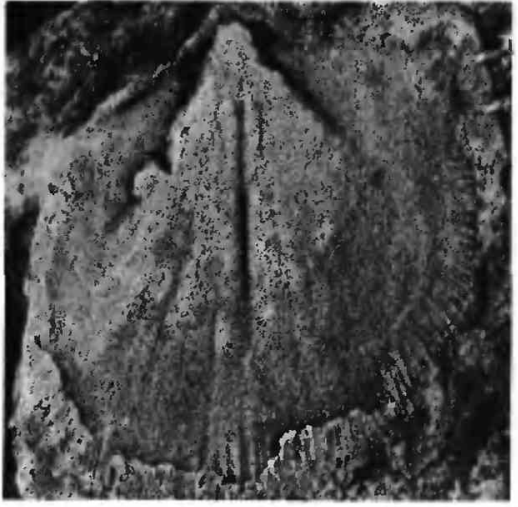

13

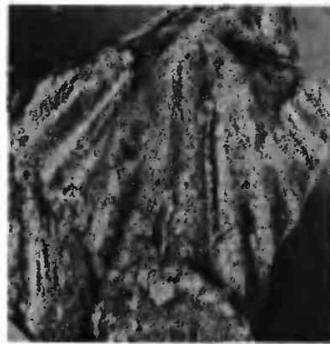

18

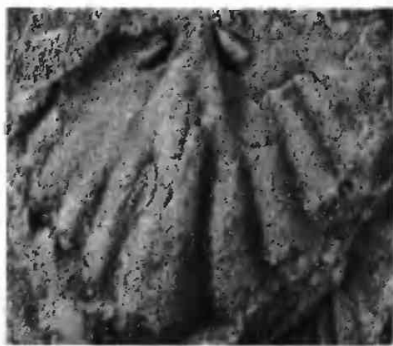

19

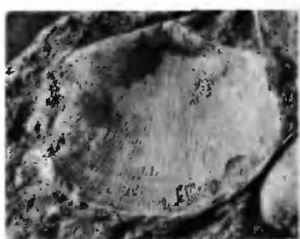

4

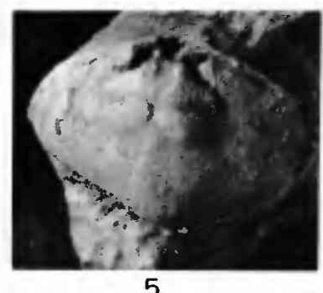

5

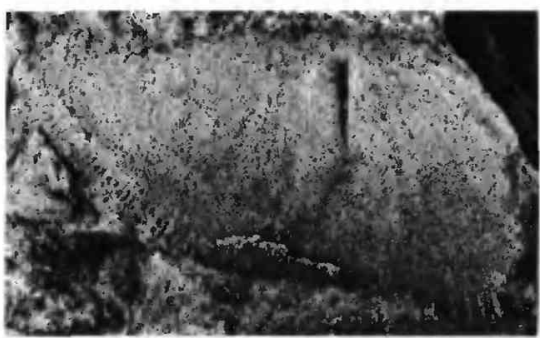

8

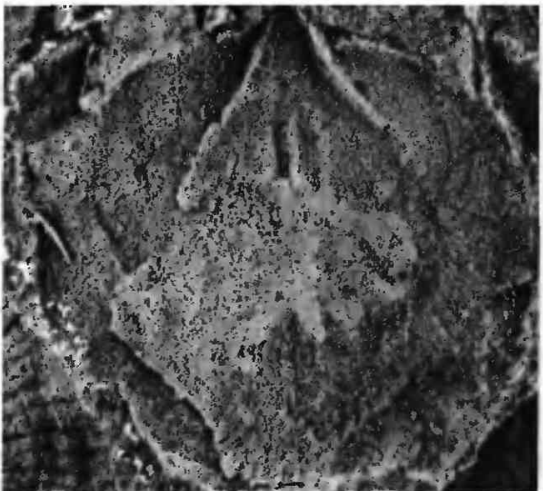

11
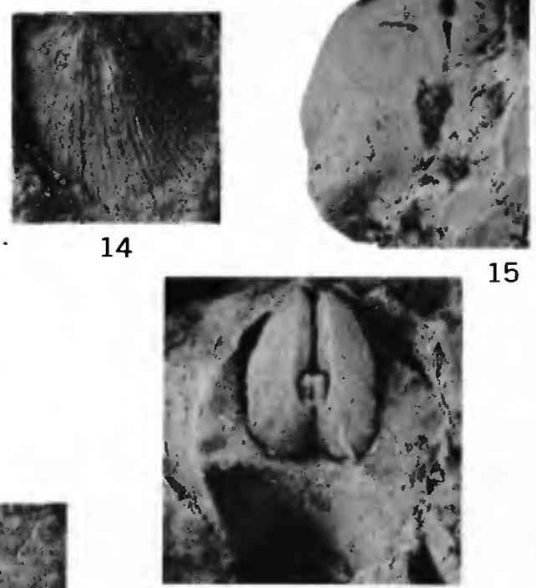

16

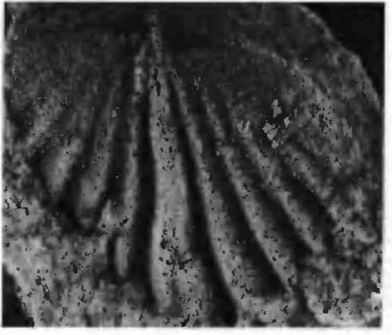

20 


\section{PLATE 2}

Figure 1-4. Euryspirifer cf. E. atlanticus (Clarke) (p. 48).

1. Internal impression of a pedicle valve $(\times 2)$. Note the presence of about six lateral plications. Pageau Farm. Upper part of the Littleton formation. MCZ 8682 C. Pl. 1, fig. 12 of Billings and Cleaves, 1934.

2. Impression of the interior of a brachial valve $(\times 2)$. Note the absence of crural plates and the presence of 10 lateral plicae. Pageau Farm. Upper part of the Littleton formation. MCZ 8664. Pl. 2, fig. 4 of Billings and Cleaves, 1934.

3. Impression of the interior of a pedicle valve $(\times 2)$. Pageau Farm. Upper part of the Littleton formation. MCZ 8663. Pl. 2, fig. 3 of Billings and Cleaves, 1934.

4. Impression of the interior of a pedicle valve $(\times 2)$. Note the flabellate muscle field which bears the impress of the external ornamentation. Pageau Farm. Upper part of the Littleton formation. MCZ 8662. Pl. 2, fig. 2 of Billings and Cleaves, 1934.

5-7. Brachyspirifer cf. B. perimele (Clarke) (p. 48).

5. Impression of the interior of a pedicle valve $(\times 1)$. Note the nearly obsolete dental lamellae and the sharply demarcated outline of the muscle impressions. Dalton Mountain. Base of the Littleton formation. USNM 125510.

6. Impression of the interior of a pedicle valve $(\times 2)$. Note the deeply impressed muscle field. Dalton Mountain. Base of the Littleton formation. USNM $125508 \mathrm{~A}$.

7. Impression of the interior of a pedicle valve $(\times 2)$. Note the relative width of the sulcus and first lateral plication as contrasted with those of Euryspirifer ef. E. atlanticus. Base of the Littleton formation. USNM $125524 \mathrm{~A}$.

8-12. Protoleptostrophia cf. P. blainvillei (Billings) (p. 48).

8. Impression of the interior of a brachial valve $(\times 1)$. Note the cardinal process lobes, the deeply impressed adductor scars, the pustulose genital areas, the absence of socket plates, and the absence of a large chilidium. Pageau Farm. Upper part of the Littleton formation. USNM 125520 A.

9. Partially exfoliated pedicle valve $(\times 1)$. Note the flabellate impression of the muscle field and the pustulose genital area. Pageau Farm. Upper part of the Littleton formation. MCZ 8671. Pl. 1, fig. 1 of Billings and Cleaves, 1934.

10. Impression of the exterior of a pedicle valve $(\times 1)$. Pageau Farm. Upper part of the Littleton formation. MCZ $8671 \mathrm{~A}$.

11. Impression of the exterior of a pedicle valve $(\times 1)$. Pageau Farm. Upper part of the Littleton formation. USNM 125501.

12. Exterior of a pedicle valve $(\times 2)$. Pageau Farm. Upper part of the Littleton formation. MCZ 8674. Pl. 1, fig. 4 of Billings and Cleaves, 1934. 
GEOLOGICAL SURVEY

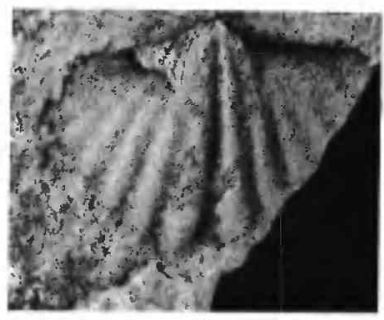

1

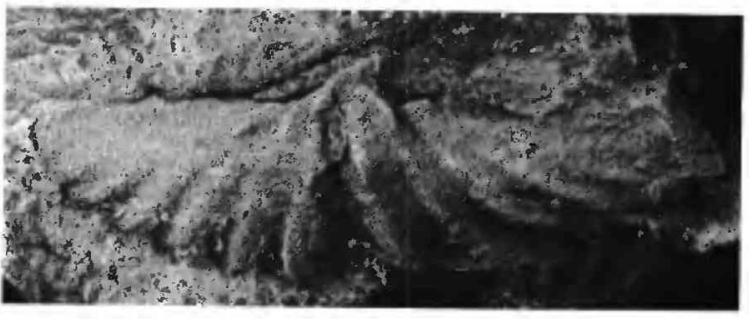

3

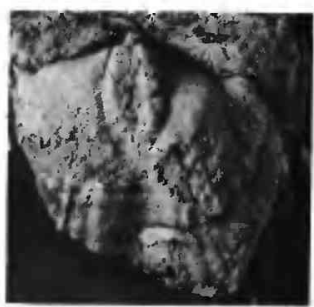

5

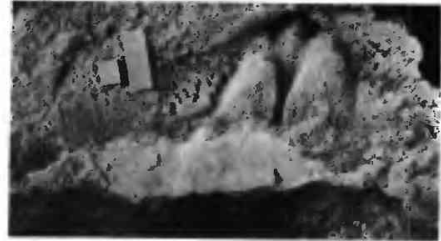

8

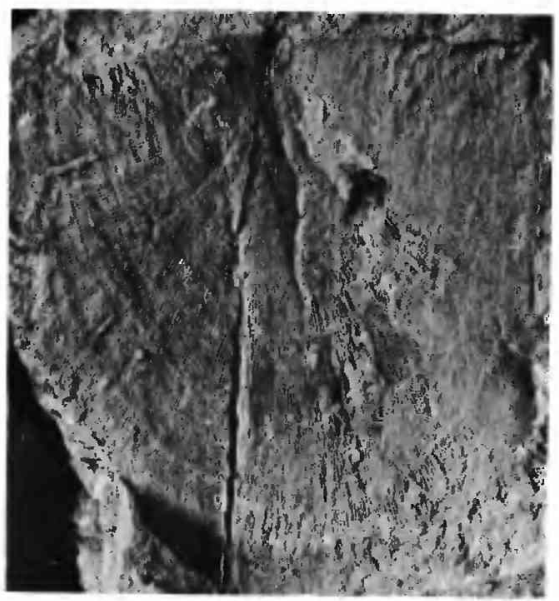

11

6

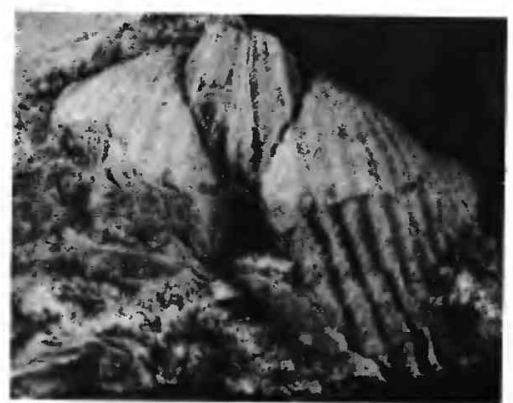

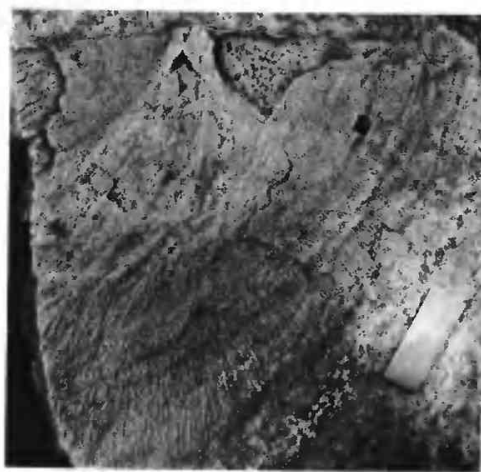

9
PROFESSIONAL PAPER 334 PLATE 2

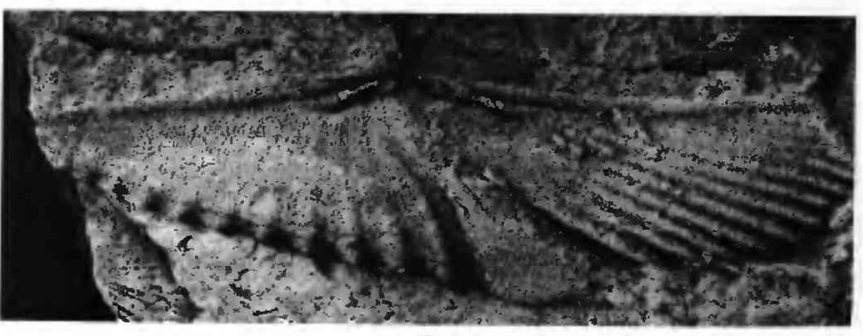

2

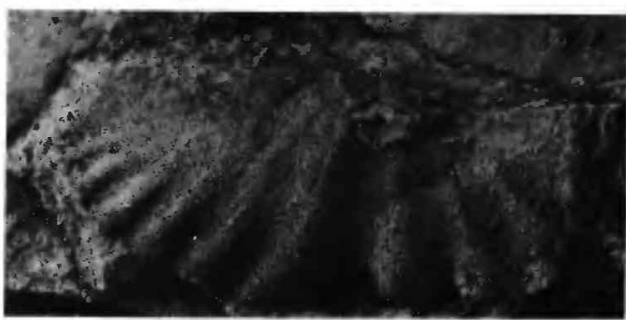

4
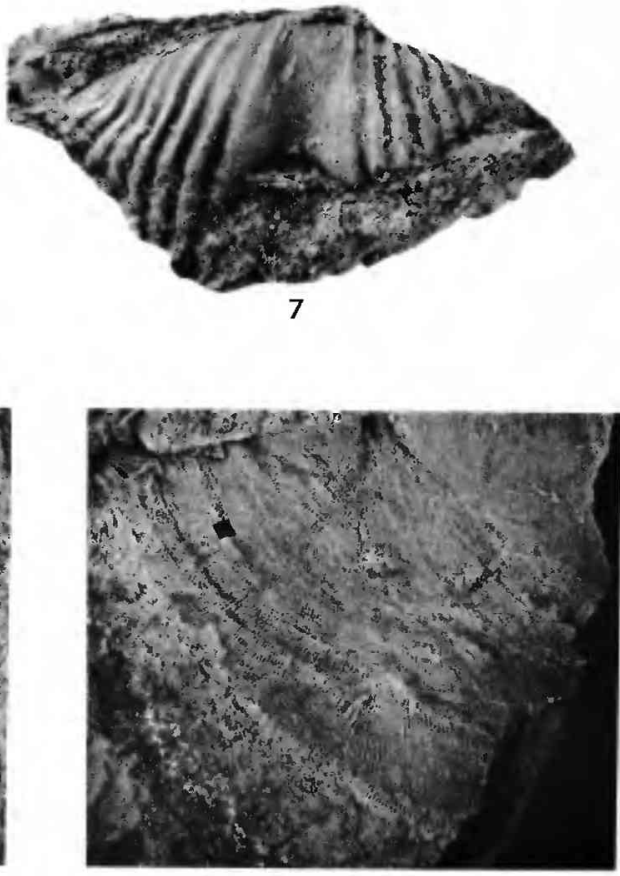

10

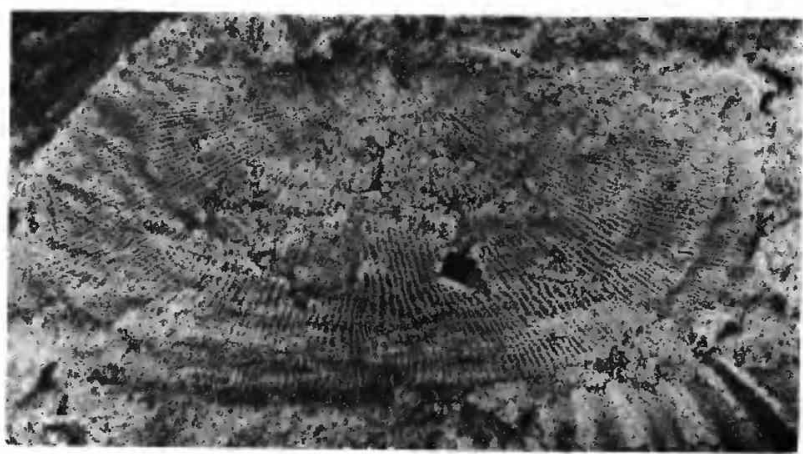

12 


\section{PLATE 3}

Figure 1. Schuchertella? sp. (p. 49).

Internal impression of a brachial valve $(\times 2)$. Mormon Hill. Upper part of the Littleton formation. MCZ 8670. Pl. 1, fig. 9 of Billings and Cleaves, 1934.

2. Leptaena "rhomboidalis" (Wilckens) (p. 49).

Impression of the exterior of a pedicle valve $(\times 2)$. Mormon Hill. Upper part of the Littleton formation. MCZ 8673.

3-9. "Chonetes" cf. "C." nectus Clarke (p. 49).

3. Impression of interior of a pedicle valve $(\times 2)$. Pageau Farm. Upper part of the Littleton formation. MCZ $8679 \mathrm{~A}$.

4. Impression of exterior of a brachial valve $(\times 3)$. Dalton Mountain. Base of Littleton formation. USNM $125514 \mathrm{~B}$.

5. Impression of exterior of a brachial valve $(\times 2)$. Pageau Farm. Upper part of Littleton formation. MCZ $8678 \mathrm{C}$.

6. Impression of exterior of a brachial valve $(\times 2)$. Pageau Farm. Upper part of Littleton formation. MCZ $8679 \mathrm{H}$. Pl. 1, fig. 14 of Billings and Cleaves, 1934.

7. Impression of exterior of a brachial valve $(\times 2)$. Pageau Farm. Upper part of Littleton formation. MCZ 8678 A. Pl. 1, fig. 15 of Billings and Cleaves, 1934.

8. Impression of interior of a pedicle valve $(\times 2)$. Pageau Farm. Upper part of Littleton formation. USNM 125509.

9. Impression of interior of brachial valve $(\times 3)$. Dalton Mountain. Base of Littleton formation. USNM $125514 \mathrm{~A}$.

10-13. Eodevonaria cf. E. arcuata (Hall) (p. 49).

10. Impression of interior of pedicle valve $(\times 2)$. Dalton Mountain. Base of Littleton formation. USNM 125515.

11. Impression of interior of pedicle valve $(\times 1)$. Pageau Farm. Upper part of Littleton formation. USNM 125521.

12. Impression of interior of pedicle valve (posterior view) $(\times 2)$. Note denticulations on left part of figure. Mormon Hill. Upper part of Littleton formation. MCZ 9412.

13. Impression of interior of pedicle valve $(\times 1)$. Mormon Hill. Upper part of Littleton formation. MCZ 9412.

14-20. Amphigenia ef. A. parva Clarke (p. 49).

14. Impression of exterior of brachial valve $(\times 1)$. Pageau Farm. Upper part of Littleton formation. USNM $125517 \mathrm{~A}$.

15. Impression of interior of brachial valve $(\times 1)$. Pageau Farm. Upper part of Littleton formation. USNM $125523 \mathrm{~B}$.

16. Impression of interior of brachial valve $(\times 1)$. Dalton Mountain. Base of Littleton formation. USNM 125506.

17. Impression of interior of pedicle valve $(\times 2)$. Dalton Mountain. Base of Littleton formation. USNM $125508 \mathrm{~B}$.

18. Impression of interior of pedicle valve $(\times 1)$. Pageau Farm. Upper part of Littleton formation. USNM 125511.

19. Impression of interior of brachial valve $(\times 2)$. Pageau Farm. Upper part of Littleton formation. USNM 125522.

20. Impression of interior of pedicle valve $(\times 2)$. Pageau Farm. Upper part of Littleton formation. MCZ 8681 .

21-25. Prionothyris? sp. (p. 49).

21. Impression of interior of pedicle valve $(\times 1)$. Pageau Farm. Upper part of Littleton formation. USNM $125504 \mathrm{~A}$.

22. Impression of interior of brachial valve $(\times 1)$. Pageau Farm. Upper part of Littleton formation. USNM 125527.

23. Silicified cardinalia $(\times 3)$. Pageau Farm. Upper part of Littleton formation. USNM 125516.

24. Impression of interior of pedicle valve $(\times 1)$. Pageau Farm. Upper part of Littleton formation. USNM $125512 \mathrm{~B}$.

25. Impression of interior of brachial valve $(\times 1)$. Pageau Farm. Upper part of Littleton formation. USNM $12550 \mathrm{~B}$.

26. Brachiopod? (p. 47).

Impression of exterior of questionable brachiopod $(\times 2)$. Elevation of 2,670 feet, northern slide, on the east slope of Mount Clough, Moosilauke quadrangle, New Hampshire. Littleton formation. MCZ 8709.

27. Tentaculites sp. (p. 50).

Impression of interior $(\times 2)$. Pageau Farm. Upper part of Littleton formation. MCZ 27097. Pl. 2, fig. 6 of Billings and Cleaves, 1934.

\section{(Continued)}


GEOLOGICAL SURVEY

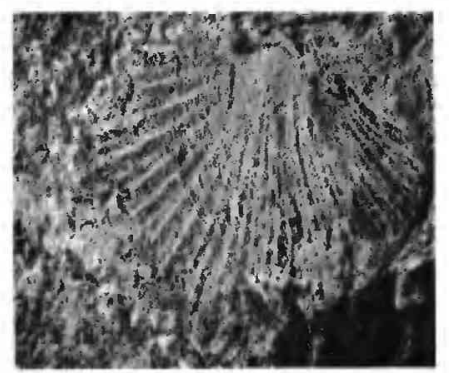

$$
1
$$

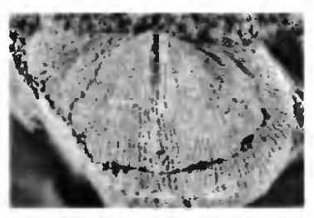

10

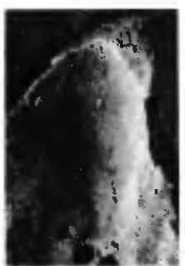

14

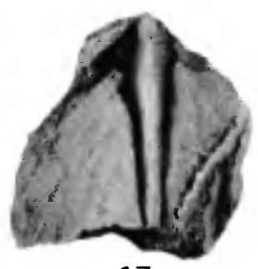

17

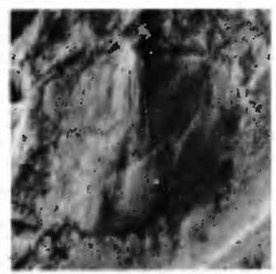

21

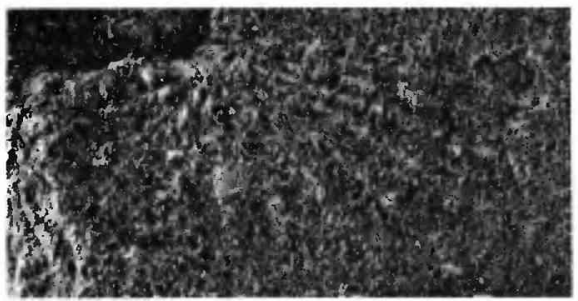

26

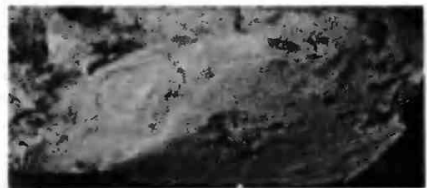

28

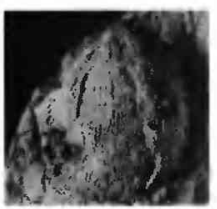

11

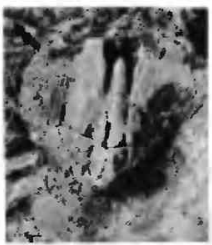

16
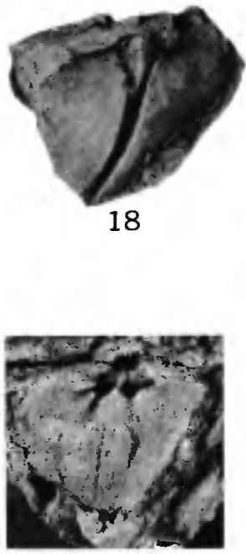

22

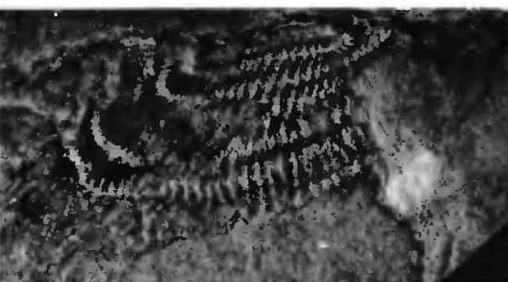

2

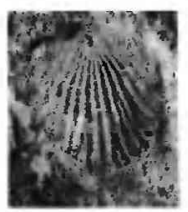

6

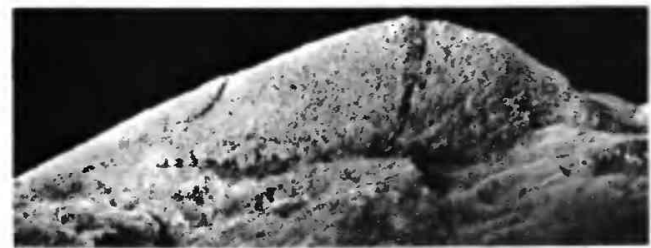

12

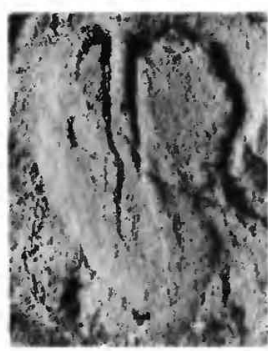

19
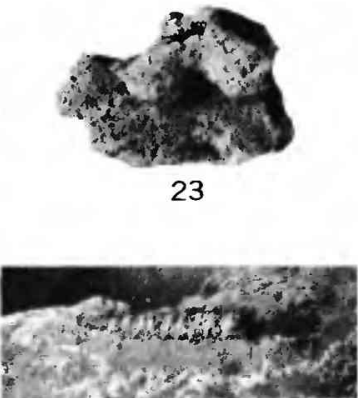

27

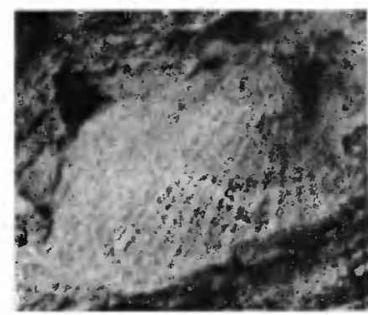

29

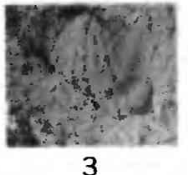

PROFESSIONAL PAPER 334 PLATE 3
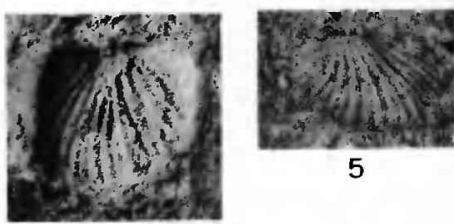

5
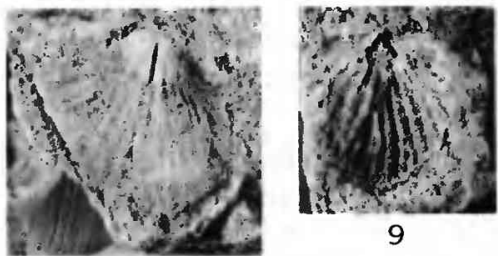

9

8

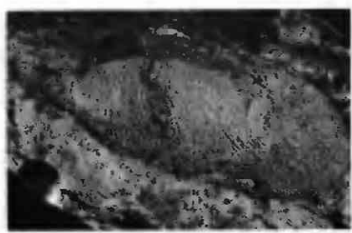

13

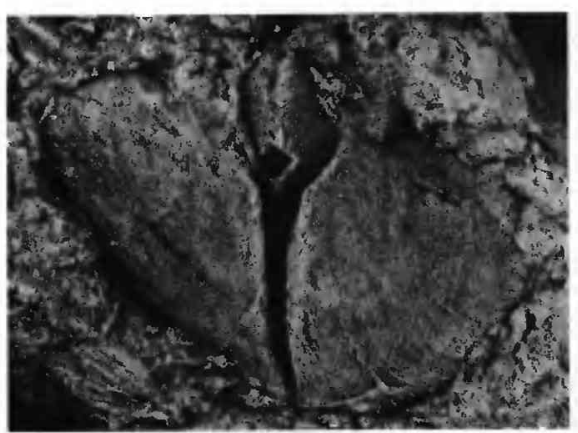

20
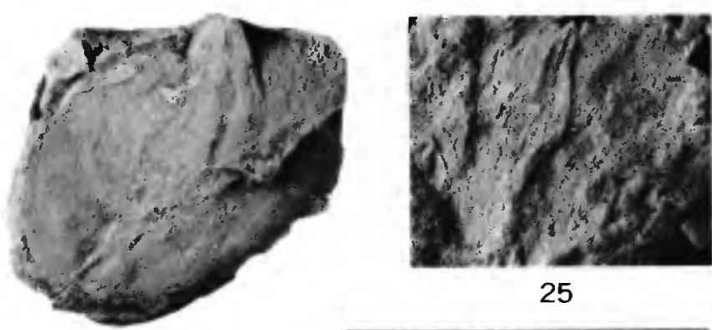

25

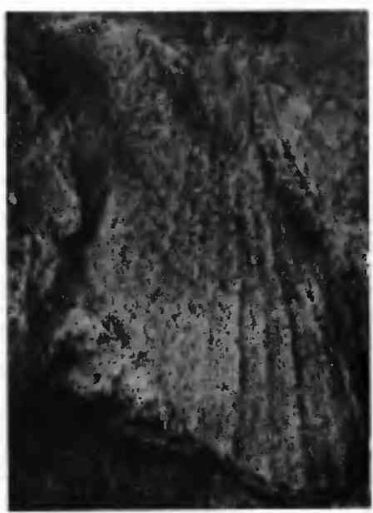

31

BRACHIOPODS AND OTHER FOSSILS FROM THE LITTLETON FORMATION 


\section{PLATE 3 - Continued}

FIGURE 28. Unidentified pelecypod (p. 50).

Impression of interior of right valve (× 1). Dalton Mountain. Base of Littleton formation. USNM 125502 B. 29-31. Unidentified pterineoid pelecypods (p. 50).

29. Impression of interior of left valve $(\times 2)$. Pageau Farm. Upper part of Littleton formation. MCZ 15058. Pl. 2, fig. 7 of Billings and Cleaves, 1934.

30. Impression of interior of left valve $(\times 2)$. Pageau Farm. Upper part of Littleton formation. MCZ 15056. Pl. 2, fig. 5 of Billings and Cleaves, 1934.

31. Impression of interior of left valve $(\times 2)$. Pageau Farm. Upper part of Littleton formation. MCZ 15057. Pl. 2, fig. 6 of Billings and Cleaves, 1934. 